\title{
Colletotrichum systematics: Past, present and prospects
}

\author{
Sharma $G^{1,2, *}$ and Shenoy BD $^{3}$ \\ ${ }^{1}$ Department of Plant Pathology and Weed Research, Agriculture Research Organization, The Volcani centre, Bet \\ Dagan - 7528809, Israel \\ ${ }^{2}$ Present address: Regional Centre for Biotechnology, NCR Biotech Cluster, Faridabad - 121001, Haryana, India \\ ${ }^{3}$ CSIR-National Institute of Oceanography, Regional Centre, 176, Lawsons Bay Colony, Vishakhapatnam - 530017, \\ Andhra Pradesh, India
}

Sharma G, Shenoy BD. 2016 - Colletotrichum systematics: Past, present and prospects. Mycosphere 7(8) 1093-1102, Doi 10.5943/mycosphere/si/2c/2

\begin{abstract}
Colletotrichum is one of the serious plant pathogens, with worldwide distribution, causing anthracnose in economically important crops. Every year many research papers and reports are published on Colletotrichum phylogeny and taxonomy. Many novel Colletotrichum species have been described based on morphological characters and multi-locus phylogenetic analysis. There is, however, a need to develop a consensus among researchers on the gene sets to be used in sequencebased identification and resolution of cryptic species of Colletotrichum. Though a polyphasic approach is recommended, it is not fully enforced in many publications. In this paper, the methods prevalent in Colletotrichum systematics are discussed, which is followed by our suggestions towards developing a stable and reliable classification system for Colletotrichum.
\end{abstract}

Key words - anthracnose - barcoding - identification - morphology - new taxa - polyphasic taxonomy

\section{Introduction}

Colletotrichum (Glomerellaceae, Sordariomycetes, Ascomycota) is one of the top 10 economically important fungal pathogens (Dean et al. 2012). This is based on its perceived scientific and economical importance. Colletotrichum species cause anthracnose in diverse hostplants such as fruit-plants, vegetables and ornamentals. The diseases symptoms include, but not limited to, blight, fruit-lesion, fruit-rot and leaf-wilt (Bailey \& Jeger 1992, Hyde et al. 2009a, b, 2014, Phoulivong et al. 2010, 2011, Rojas et al. 2010, Su et al. 2011, Cannon et al. 2012, Damm et al. 2012a, b, 2013, Weir et al. 2012, Doyle et al. 2013, Huang et al. 2013, Sharma et al. 2013a, 2014, 2015a, Udayanga et al. 2013). They are responsible for post-harvest fruit rot of agricultural commodities such as apple, banana, chilli, coffee and mango (Bailey \& Jeger 1992). Extensive yield loss has been reported due to the damages caused by Colletotrichum infection, which substantiates the severity of Colletotrichum as a post-harvest pathogen (Prusky 1996, Droby et al. 2011, Snowdon 2010, Swamy 2012). This has implications in plant-quarantine decisions as Colletotrichum-infected commodities are not suitable for the import/ export purpose, leading to revenue loss (Chakrabarty et al. 2011). Colletotrichum species are cosmopolitan in distribution and exhibit diverse host-associations. Multiple Colletotrichum species can infect a host plant genus (Coffea - Nguyen et al. 2009, Prihastuti et al. 2009, Silva et al. 2012b; Mangifera - Phoulivong et al. 2010, Lima et al. 2013, Sharma et al. 2013a, 2015b) or conversely a single Colletotrichum 
species can infect many host plants ( $C$. boninense - Moriwaki et al. 2003, Damm et al. 2012a; $C$. fructicola - Prihastuti et al. 2009, Phoulivong et al. 2010, Weir et al. 2012, Sharma et al. 2013a, 2014, Udayanga et al. 2013). Some species of Colletotrichum species reportedly infect humans (Cano et al. 2004, Shivaprakash et al. 2011, Figtree et al. 2013, Natarajan et al. 2013).

\section{Colletotrichum systematics: the history}

Colletotrichum was originally described under the name Vermicularia by Tode (1790), but later it was revised as Colletotrichum by Corda (1837). Colletotrichum was classified in "Melanconiales" under "Coelomycetes" (Hawksworth, 1983). The epithets Colletotrichum and Vermicularia were used indiscriminately during the $19^{\text {th }}$ and early $20^{\text {th }}$ centuries for a range of species, which are now classified in Colletotrichum (Sutton 1992). Colletotrichum is distinguished from Vermicularia by the presence of marginal setae as compared to the setae dispersed throughout the conidiomata in Vermicularia (Clements \& Shear 1931). However, Duke (1928) had earlier demonstrated that conidiomatal structure and form, the presence/ absence of setae and their arrangement within the acervulus are extremely variable and of no taxonomic significance at the genus level. This resulted in transfer of a large number of species from Vermicularia to Colletotrichum (Duke 1928, Cannon et al. 2012). Gloeosporium, a morphologically similar anamorph, also posed problems during identification, and distinguishing it from Colletotrichum was tough, as although Gloeosporium species did not produce setae, some could generate setae on certain substrates (Baker et al. 1940). Earlier G. lindemuthianum was transferred to Colletotrichum by Briosi \& Cavara (1889). Lately, G. kaki Hori has been transferred to C. horii (Weir \& Johnston 2010) and G. pedemontanum has been synonymized as C. gloeosporioides (Weir et al. 2012).

\section{Colletotrichum or Glomerella: solution to nomenclatural perplexity}

Colletotrichum, in its traditional sense, represents anamorphic features, while Glomerella has been used to represent its teleomorph. As on $17^{\text {th }}$ August 2016, the term "Colletotrichum" produced 771 search results, while the term "Glomerella" produced 89 search results in Mycobank (www.mycobank.org). Similar results can also be obtained in the Index Fungorum (http://www.indexfungorum.org). However, these numbers are high as compared to the current number of the accepted species names under Colletotrichum (Cannon et al. 2012). There are currently about 150 accepted species of Colletotrichum (Cannon et al. 2012, Peng et al. 2012, 2013, Damm et al. 2013, Doyle et al. 2013, Lima et al. 2013, Liu et al. 2013a, b, 2015, Manamgoda et al. 2013, Udayanga et al. 2013, Liu et al. 2016b, Niu et al. 2016, Wang et al. 2016), out of which only 30 species are associated with Glomerella stage (Edgerton 1901, Spaulding \& Schrenk 1903, Shear \& Wood 1913, Petch 1917, Lehman \& Wolf 1926, Stevens 1931, Arx \& Mueller 1954, Politis 1975, Sutton 1992, Guerber \& Correll 2001, Hyde et al. 2009b, Damm et al. 2012a, b, Cannon et al. 2012), indicating at the possible infrequent occurrence of Glomerella in nature/ culture media. A comprehensive list for the anamorph-teleomorph connections was provided by Cannon et al. (2012). Nevertheless, the identification of many Glomerella species remains uncertain and warrants a revision based on a polyphasic approach (discussed later).

Considering the ambiguity regarding the "preferred name" of pleomorphic fungi, revisions were made in the International Code of Botanical Nomenclature (ICBN; Vienna Code); now known as the International Code of Nomenclature for algae, fungi and plants (ICN; Melbourne Code) in the Eighteenth International Botanical Congress held in Melbourne in July 2011 (Norvell 2011). The Article 59 of the ICN has been modified and it now establishes a code of "one fungus: one name". Thus, all the fungal species exhibiting separate asexual and sexual life cycles will be described with only one formal name. In order to deal with the nomenclatural issues associated with Colletotrichum, International Sub-commission on Colletotrichum Taxonomy (ISCT) has been established under the International Commission on the Taxonomy of Fungi (ICTF, http://www.fungaltaxonomy.org/subcommissions). The epithet Colletotrichum is more preferred (84\% based on statistics) as compared to Glomerella (Cai \& Weir 2012). More information on the history of classification and nomenclature are detailed in a recent review by Cannon et al. (2012). 


\section{Colletotrichum taxonomy: species recognition criteria}

There are four main species recognition criteria: (1) Biological species recognition criterion advocates the model of inter-sterility between two distinct species. (2) Morphological species recognition criterion advocates the morphological divergence between species. (3) Ecological species recognition criterion advocates the acclimatization of a species to a specific geographical niche. (4) Phylogenetic species recognition criterion advocates the molecular divergence between closely related lineages based on DNA sequence data (Taylor et al. 2000, Giraud et al. 2008, Cai et al. 2011). In case of Colletotrichum, formerly identification based on morphology (morphological species recognition criterion) was preferred, but with the development and ease of DNA sequencing technologies, phylogenetic species recognition criterion has become popular. Nevertheless, identification of a fungal species based on morpho-taxonomic characters is not completely reliable without the establishment of the model of inter-sterility (Biological species recognition criterion).

Morpho-taxonomic characters such as shape and size of conidia, setae and appressoria, together with host-specificity were traditionally used to define Colletotrichum species (von Arx 1957, Sutton 1980, 1992). Relying only on morphological characteristics of a culture, von Arx (1957) reported eleven Colletotrichum species, which increased to 40 based on host-specificity and morphology (Sutton 1980). Description of 40 Colletotrichum species along with a key-based identification system for Colletotrichum was provided by Sutton (1980), which helps in preliminary identification. Following this trend, around 900 Colletotrichum species names were designated by various researchers (Sutton 1992). Species identification and classification based solely on morphotaxonomic characters is highly prone to errors and, in many cases such as Colletotrichum species complexes, unreliable due to the presence of overlapping morphological characters (Cai et al. 2009, Hyde et al. 2009a). Besides, Colletotrichum host-association reports are made with partial sampling restricted to a particular host or site/s, not always supplemented with pathogenicity assays; accounting for limited understanding of host-specificity. Diverse lifestyle and survival strategies in Colletotrichum is responsible for the high genetic diversity and complexities in the taxonomic placement of the member species of Colletotrichum. Only a few species are known to be hostspecific, such as C. musae (Musa sp.), C. nupharicola (Nuphar lutea), C. lindemuthianum (beans). Hence, species recognition solely based on morphology and host-specificity in Colletotrichum is not advisable.

Advancements in molecular biology provided new DNA-sequence based identification tools (Bruns et al. 1991, Shenoy et al. 2007a). Some of the initial studies included: identification based on analysis of restriction fragment length polymorphism (RFLP), use of polymerase chain reaction (PCR) based technique to assess the random amplified polymorphic DNA (RAPD) and sequence data of 5.8S ribosomal RNA and flanking internal transcribed spacers 1 \& 2 (ITS) region (Welsh \& McClelland 1990, White et al. 1990, Williams et al. 1990, Sreenivasprasad et al. 1996). Although ITS/5.8S rRNA gene region offers a good species-level resolution in many fungal groups (Nilsson et al. 2008, Schoch et al. 2012), it offers moderate species resolution in Colletotrichum (Cai et al. 2009, Crouch et al. 2009, Damm et al. 2009, 2010, Gazis et al. 2011, Cannon et al. 2012, Sharma et al. 2013b).

Application of a single species recognition criterion in all cases is essentially not possible (Giraud et al. 2008). Thus recent studies highlight the need to identify a secondary barcode for Colletotrichum (Sharma et al. 2013a, 2015a) and recommend a polyphasic approach towards characterization of Colletotrichum species (Cai et al. 2009, Cannon et al. 2012).

\section{Polyphasic taxonomy}

Cai et al. (2009) suggested the parameters/ characters to be incorporated while describing Colletotrichum species using a polyphasic approach. Polyphasic taxonomy includes the classification of a fungal species using different parameters such as: morphology (colony morphology, conidia, presence or absence of setae, production of aprèssoria and ascospores), multilocus sequence data, pathogenicity assay, biochemical testing, secondary metabolite production and utilization of carbon source. Following their recommendations, multi-locus phylogenetic analysis 
has become prevalent and many novel species have been described based on morphology, phylogenetic analyses and pathogenicity testing (Damm et al. 2009, 2012a, b, 2013, Doyle et al. 2013, Lima et al. 2013, Liu et al. 2013a, b, Manamgoda et al. 2013, Peng et al. 2013, Sharma et al. 2013a, 2015a, Udayanga et al. 2013, Weir et al. 2012). In a few cases results for biochemical testing have also been provided (Prihastuti et al. 2009). An example of the usefulness of polyphasic approach is the merging of $C$. capsici with $C$. truncatum. Colletotrichum capsici was initially described as Vermicularia capsici Syd. (Sydow, 1913) in India and epitypified by Shenoy et al. (2007b). However, based on multi-locus analysis using five genes (act, chs 1, gapdh, his3, ITS) coupled with morphological characterization $C$. capsici was shown to be a synonym of $C$. truncatum sensu stricto within $C$. truncatum species complex (Damm et al. 2009). Similar approach has been employed to resolve $C$. acutatum, $C$. boninense, $C$. gloeosporioides and $C$. orbiculare species complexes (Damm et al. 2012 a, b, 2013, Weir et al. 2012). The biochemical testing and analysis of secondary metabolites synthesized by Colletotrichum isolates is not popular in Colletotrichum taxonomy. Hence, it is suggested that the parameters recommended by Cai et al. (2009) are employed while characterizing a Colletotrichum species.

\section{Need for a secondary barcode}

Earlier, Colletotrichum species were identified based on morphological characters and mainly ITS sequence data (the fungal barcode region) (Freeman et al. 2000, Martínez-Culebras et al. 2000, Afanador-Kafuri et al. 2003, Cano et al. 2004). In some studies, $\beta$-tubulin (tub2) sequences have also been used for phylogenetic analysis (Myllys et al. 2002, Than et al. 2008), but use of multi-locus sequence dataset was not prevalent. Thus, the accuracy of species names in many of these reports remain doubtful. In the absence of a reliable secondary barcode marker, researchers are relying more on phylogenetic analysis based on the multi-locus sequence dataset [actin (act), calmodulin ( $\mathrm{cal}$ ), chitin synthase ( $c h s 1)$, glutamine synthase $(g s)$, glyceraldehyde 3-phosphate dehydrogenase (gapdh), histone (his3) and tub2] to identify and classify a Colletotrichum species. Multigene phylogeny has proven to be beneficial in resolving cryptic species within major species complexes of Colletotrichum. However, the selection of the genes used for phylogenetic analysis has varied according to the species complex [C. acutatum - act, chs1, gapdh, his3, ITS, tub2; C. boninense - act, cal, chs1, gapdh, his3, ITS, tub2; C. destructivum/ dematium/ truncatum - act, chs1, gapdh, his3, ITS, tub2; C. gigapsorum - act, chs1, gapdh, ITS, tub2; C. gloeosporioides act, cal, chs1, gapdh, ITS and C. orbiculare - act, chs1, gapdh, gs, his3, ITS, tub2] (Damm et al. 2009, 2012 a, b, 2013, 2014, Weir et al. 2012, Liu et al. 2015). Moreover, there is no consensus among researchers working on Colletotrichum taxonomy as to which gene markers should be used to define and delimit a species within different species complexes of Colletotrichum. Thus it is important to generate an agreement on this issue. It is also important to develop datasets for a secondary barcode marker to accurately identify cryptic species within the major species complexes of Colletotrichum. Gene markers such as intronic sequence of $5^{\prime}$ region of the translation elongation factor 1- $\alpha$ (5'tefl), ribosomal polymerase largest subunit $(r p b l)$ and intergenic spacer region between apn2 and Mat1-2 genes (ApMat) have been shown to be useful in resolution of clades at $C$. gloeosporioides species complex level (Rojas et al. 2010, Silva et al. 2012a, Doyle et al. 2013, Sharma et al. 2013a). Due to the availability of limited reference dataset in case of rpbl and 5 'tefl, their utility in Colletotrichum phylogeny has not been fully realized. In addition, presence of large region of homoplastic introns in case of $5^{\prime}$ tefl also limits the usage of this marker at species complex level (Rojas et al. 2010). ApMat gene-marker was reported to provide better resolution (Silva et al. 2012a, Doyle et al. 2013, Sharma et al. 2013a, 2015a) as compared to the five genemarkers used by Weir et al. (2012). There are no reported studies on secondary barcode for the other species complexes of Colletotrichum, such as C. acutatum, C. boninense, C. graminicola or C. truncatum. Establishing a single gene-marker which will serve as a secondary barcode for the species complexes is warranted for the advancement of Colletotrichum taxonomy. 


\section{Conclusions and future prospects}

Rapid and accurate species identification of Colletotrichum species is essential, as it plays a crucial role in plant quarantine issues involving export-import of agricultural commodities (Rossman \& Palm-Hernández 2008). However, there is no consensus among mycologists and plant pathologists working on Colletotrichum on the taxonomic approach and characters to be employed while identifying and describing a new Colletotrichum species or pathogen. There is a need for a reliable secondary barcode marker for the accurate identification of Colletotrichum species. ApMat marker has been projected as a putative secondary barcode for $C$. gloeosporioides species complex (Sharma et al. 2013a, 2015a). Using ApMat marker based analysis, seven species within $C$. gloeosporioides species complex $(C$. communis, $C$. dianesei, $C$. endomangiferae, $C$. hymenocallidis, $C$. jasmini-sambac, $C$. murrayae, $C$. siamense), having phylogenetic affinities with $C$. siamense sensu stricto were considered to be part of a separate species complex called as $C$. siamense species complex (Sharma et al. 2015a). These species were previously described as separate species based on their host and ecological diversity, from 2009 to 2014 (Yang et al. 2009, Wikee et al. 2011, Peng et al. 2012, Doyle et al. 2013, Lima et al. 2013, Vieira et al. 2014); but considered as conspecific to $C$. siamense by Weir et al. (2012). Later, Liu et al. (2015) demonstrated that a combination of ApMat and gs regions is useful for species delimitation of five species ( $C$. fructivorum, $C$. rhexiae, $C$. kahawae, $C$. temperatum, and $C$. jiangxiense) which were inseparable using Apmat marker only, within C. gloeosporioides species complex. To test the hypothesis that $C$. siamense $s$. $l$. is a species complex, Liu et al. (2016a) have recently compared the gene trees generated using different gene sets (ApMat, cal, gapdh, gs, ITS, tub2) and established $C$. siamense s. $l$. as a single species based on multi-locus GCPSR, pairwise homoplasy index test, coalescent analyses, cross mating and genetic recombination tests. Thus, our search for a secondary barcode for Colletotrichum still continues. It is suggested that researchers working on Colletotrichum taxonomy consider incorporating certain measures to illustrate a new species as followed in bacterial taxonomy (Lapage et al. 1990, Logan et al. 2009, Sarethy et al. 2014). There are a few parameters which should be set and agreed upon by the consensus of fellow researchers: (1) Minimum number of isolates included in a study; (2) The set of genes to be sequenced and analyzed; (3) Biochemical tests to be performed; (4) Type of phylogenetic analysis to be done; (5) The need for mating compatibility test; (6) Results of pathogenicity testing; and (7) Substrate utilization test. It is hoped that researchers will work hand-in-hand and finalize the parameters for describing novel species of Colletotrichum.

\section{Acknowledgements}

Authors thank the anonymous reviewers for their invaluable suggestions in improving this manuscript. Gunjan Sharma thanks Planning and Budget Committee, Israel for research fellowship. B. D. Shenoy thanks CSIR-National Institute of Oceanography, India and acknowledges OLP1211 as funding source.

\section{References}

Afanador-Kafuri L, Minz D, Maymon M, Freeman S. 2003 - Characterization of Colletotrichum isolates from tamarillo, passiflora, and mango in Colombia and identification of a unique species from the genus. Phytopathology 93, 579-587.

Arx JA von. 1957 - Die arten der GaHung Colletolrichum Cda. Phytopathologische Zeitschrift. 29, 413-468.

Arx von, Mueller AE. 1954 - Beiträge zur kryptogamenflora der Schweiz. 11, 196.

Bailey JA, Jeger MJ. 1992 - Colletotrichum: Biology, pathology and control. J. A. Bailey and M. J. Jeger (eds.) CAB International, Wallingford, England, United Kingdom.

Baker RED, Crowdy SH, Mckee RK. 1940 - A review of latent infections caused by Colletotrichum gloeosporioides and allied fungi. Tropical Agriculture 17, 128-132. 
Briosi G, Cavara F. 1889 - I Fungi Parassiti della Piante Coltivate od utili essicati, delineati e descritti. Fasc. 2, 26-50.

Bruns TD, White TJ, Taylor JW. 1991 - Fungal Molecular Systematics. Annual Review of Ecology and Systematics 22, 525-564.

Cai L, Giraud T, Zhang N, Begerow D, Cai G, Shivas RG. 2011 - The evolution of species concepts and species recognition criteria in plant pathogenic fungi. Fungal Diversity 50, 121-133.

Cai L, Weir BS. 2012 - International Subcommission on Colletotrichum Taxonomy, Inaugural General Meeting minutes, Beijing.

Cannon PF, Damm U, Johnston PR, Weir BS. 2012 - Colletotrichum - current status and future directions. Studies in Mycology 73, 181-213.

Cano J, Guarro J, Gene J. 2004 - Molecular and morphological identification of Colletotrichum species of clinical interest. Journal of Clinical Microbiology 42, 2450-2454.

Chakrabarty SK, Anitha K, Kumar GS, Babu BS, Rao RDVJ, Abraham B, Varaprasad KS. 2011 Exotic pathogen entry with crop germplasm into India-Risks and significance. Indian Journal of Plant Protection 39, 23-28.

Clements FE, Shear CL. 1931 - The genera of Fungi. Hafner Press, New York. p. 496.

Corda ACJ. 1837 - Pilze in J. Sturm. Deutschland Flora 3, 41.

Crouch JA, Clarke B, Hillman B. 2009 - What is the value of ITS sequence data in Colletotrichum systematic and species diagnosis? A case study using the falcate-spored graminicolous Colletotrichum group. Mycologia 101, 648-656.

Damm U, Baroncelli R, Cai L, Kubo Y, O’Connell R, Weir B, Yoshino K, Cannon PF. 2010 Colletotrichum: species, ecology and interactions. IMA Fungus: The Global Mycological Journal 1, 161-165.

Damm U, Cannon PF, Liu F, Barreto RW, Guatimosim E, Crous PW. 2013 - The Colletotrichum orbiculare species complex: Important pathogens of field crops and weeds. Fungal Diversity 61, 29-59.

Damm U, Cannon PF, Woudenberg JHC, Crous PW. 2012b - The Colletotrichum acutatum species complex. Studies in Mycology 73, 37-113.

Damm U, Cannon PF, Woudenberg JHC, Johnston PR, Weir BS, Tan YP, Shivas RG, Crous PW. 2012a - The Colletotrichum boninense species complex. Studies in Mycology 73, 1-36.

Damm U, Woudenberg JHC, Cannon PF, Crous PW. 2009 - Colletotrichum species with curved conidia from herbaceous hosts. Fungal Diversity 39, 45-87.

Dean R, Van Kan JAL, Pretorius ZA, Hammond-Kosack KE, Di Pietro A, Pietro DS, Rudd JJ, Dickman M, Kahmann R, Ellis J, Foster GD. 2012 - The Top 10 fungal pathogens in molecular plant pathology. Molecular Plant Pathology 13, 414-430.

Doyle VP, Oudemans PV, Rehner SA, Litt A. 2013 - Habitat and host indicate lineage identity in Colletotrichum gloeosporioides s. $l$. from wild and agricultural landscapes in North America. PloS One 8, e62394.

Droby S, Wisniewski M, Benkeblia N, Yahia EM. 2011 - Postharvest pathology of tropical and subtropical fruit and strategies for decay control. Postharvest Biology and Technology of Tropical and Subtropical Fruits 1, 194-223.

Duke MM. 1928 - The genera Vermicularia Fr. and Colletotrichum Cda. Transactions of the British Mycological Society 13, 156-184.

Edgerton CW. 1909 - The perfect stage of the cotton anthracnose. Mycologia 1, 115-120.

Figtree M, Weeks K, Chan L, Leyton A, Bowes A, Giuffre B, Sullivan M, Hudson BJ. 2013 Colletotrichum gloeosporioides sensu lato causing deep soft tissue mycosis following a penetrating injury. Medical Mycology Case Reports 2, 40-43.

Freeman S, Minz D, Jurkevitch E, Maymon M, Shabi E. 2000 - Molecular analyses of Colletotrichum species from almond and other fruits. Phytopathology 90, 608-614. 
Gazis R, Rehner S, Chaverri P. 2011 - Species delimitation in fungal endophyte diversity studies and its implications in ecological and biogeographic inferences. Molecular Ecology 20, 3001-3013.

Giraud T, Refrégier G, Le Gac M, de Vienne DM, Hood ME. 2008 - Speciation in fungi. Fungal Genetics and Biology 45, 791-802.

Guerber JC, Correll JC. 2001 - Characterization of Glomerella acutata, the teleomorph of Colletotrichum acutatum. Mycologia 93, 216-229.

Hawksworth DL, Sutton BC, Ainsworth GC. 1983 - Ainsworth and Bisby's dictionary of the fungi 7th ed. Commonwealth Mycological Institute, Kew United Kingdom. p. 445.

Huang F, Chen GQ, Hou X, Fu YS, Cai L, Hyde KD, Li HY. 2013 - Colletotrichum species associated with cultivated citrus in China. Fungal Diversity 61, 61-74.

Hyde KD, Cai L, Cannon PF, Crouch JA, Crous PW, Damm U, Goodwin PH, Chen H, Johnston PR, Jones EBG, Liu ZY, McKenzie EHC, Moriwaki J, Noireung P, Pennycook SR, Pfenning LH, Prihastuti H, Sato T, Shivas RG, Tan YP, Taylor PWJ, Weir BS, Yang YL, Zhang JZ. 2009b - Colletotrichum - names in current use. Fungal Diversity 39, 147-182.

Hyde KD, Cai L, McKenzie EHC, Yang YL, Zhang JZ, Prihastuti H. 2009a - Colletotrichum: a catalogue of confusion. Fungal Diversity 39, 1-17.

Hyde KD, Nilsson RH, Alias SA, Ariyawansa HA, Blair JE, Cai L, de Cook AWAM, Dissanayake AJ, Glockling SL, Goonasekara ID, Gorczak M, Hahn M, Jayawardena RS, van Kan JAL, Laurence MH, Lévesque CA, Li X, Liu JK, Maharachchikumbura SSN, Manamgoda DS, Martin FN, McKenzie EHC, McTaggart AR, Mortimer PE, Nair PVR, Pawlowska J, Rintoul TL, Shivas RG, Spies CFJ, Summerell BA, Taylor PWJ, Terhem RB, Udayanga D, Vaghefi N, Walther G, Wilk M, Wrzosek M, Xu JC, Yan J, Zhou N. 2014 - One stop shop: backbone trees for important phytopathogenic genera I. Fungal Diversity 67, 21-125.

Index Fungorum. 2016 - http://www.indexfungorum.org

International Commission on Taxonomy of Fungi (ICTF). 2016 http://www.fungaltaxonomy.org/subcommissions.

Kirk PM, Cannon PF, Minter DW, Stalpers JA (eds.). 2008 - Dictionary of the Fungi. CABI, Wallingford, United Kingdom.

Lapage SP, Sneath PHA, Lessel EF, Skerman VBD, Seeliger HPR, Clark WA. 1992 - International Code of Nomenclature of Bacteria (1990 Revision). American Society for Microbiology, Washington, D.C.

Lehman SG, Wolf FA. 1926 - Soybean anthracnose. Journal of Agricultural Research 33, 381-390.

Lima NB, Batista MVDA, De Morais Jr MA, Barbosa MA, Michereff SJ, Hyde KD, Câmara MP. 2013 - Five Colletotrichum species are responsible for mango anthracnose in northeastern Brazil. Fungal Diversity 61, 75-88.

Liu F, Cai L, Crous PW, Damm U. 2013a - Circumscription of the anthracnose pathogens Colletotrichum lindemuthianum and C. nigrum. Mycologia 105, 844-860.

Liu F, Damm U, Cai L, Crous PW. 2013b - Species of the Colletotrichum gloeosporioides complex associated with anthracnose diseases of Proteaceae. Fungal Diversity 61, 89-105.

Liu F, Wang M, Damm U, Crous PW, Cai L. 2016a - Species boundaries in plant pathogenic fungi: a Colletotrichum case study. BMC Evolutionary Biology 16, 81. (doi 10.1186/s12862-0160649-5)

Liu F, Weir BS, Damm U, Crous PW, Wang Y, Liu B, Cai L. 2015 - Unravelling Colletotrichum species associated with Camellia: employing ApMat and GS loci to resolve species in the $C$. gloeosporioides complex. Persoonia-Molecular Phylogeny and Evolution of Fungi 35, 6386.

Liu F, Tang G, Zheng X, Li Y, Sun X, Qi X, Zhou Y, Xu J, Chen H, Chang X, Zhang S. 2016b Molecular and phenotypic characterization of Colletotrichum species associated with anthracnose disease in peppers from Sichuan Province, China. Scientific Reports 6, 32761. 
Logan NA, Berge O, Bishop AH, Busse HJ, De Vos P, Fritze D, Seldin L. 2009 - Proposed minimal standards for describing new taxa of aerobic, endospore-forming bacteria. International Journal of Systematic and Evolutionary Microbiology 59, 2114-2121.

Manamgoda DS, Udayanga D, Cai L, Chukeatirote E, Hyde KD. 2013 - Endophytic Colletotrichum from tropical grasses with a new species $C$. endophytica. Fungal Diversity 61, 107-115.

Martínez-Culebras PV, Barrio E, García MD, Querol A. 2000 - Identification of Colletotrichum species responsible for anthracnose of strawberry based on the internal transcribed spacers of the ribosomal region. FEMS Microbiology Letters 189, 97-101.

Moriwaki J, Sato T, Tsukiboshi T. 2003 - Morphological and molecular characterization of Colletotrichum boninense sp. nov. from Japan. Mycoscience 44, 47-53.

Mycobank. 2016 - www.mycobank.org

Myllys L, Stenroos S, Thell A. 2002 - New genes for phylogenetic studies of lichenized fungi: glyceraldehyde-3-phosphate dehydrogenase and beta-tubulin genes. The Lichenologist 34, 237-246.

Natarajan SV, Rekha NS, Sharda RD, Mahalingam N. 2013 - Colletotrichum keratitis: A rare but definite clinical entity. Journal of Clinical and Diagnostic Research 7, 1430-1433.

Nguyen THP, Säll T, Bryngelsson T, Liljeroth E. 2009 - Variation among Colletotrichum gloeosporioides isolates from infected coffee berries at different locations in Vietnam. Plant Pathology 58, 898-909.

Nilsson RH, Kristiansson E, Ryberg M, Hallenberg N, Larsson K-H. 2008 - Intraspecific ITS variability in the kingdom fungi as expressed in the internal sequence databases and its implications for molecular species identification. Evolutionary Bioinformatics 4, 193-201.

Niu X, Gao H, Qi J, Chen M, Tao A, Xu J, Dai Z, Su J. 2016 - Colletotrichum species associated with jute (Corchorus capsularis L.) anthracnose in southeastern China. Scientific reports 6, 25179.

Norvell LL. 2011 - Fungal nomenclature. 1. Melbourne approves a new Code. Mycotaxon 116, 481-490.

Peng L, Yang YL, Hyde KD, Bahkali AH, Liu ZY. 2012 - Colletotrichum species on Citrus leaves in Guizhou and Yunnan provinces, China. Cryptogamie Mycologie 33, 267-283.

Peng LJ, Sun T, Yang YL, Cai L, Hyde KD, Bahkali AH, Liu ZY. 2013 - Colletotrichum species on grape in Guizhou and Yunnan provinces, China. Mycoscience 54, $29-41$.

Petch T. 1917 - Additions to Ceylon fungi. Annals of the Royal Botanic Gardens of Peradeniya 6, $195-256$.

Phoulivong S, Cai L, Chen H, McKenzie EHC, Abdelsalam K, Chukeatirote E, Hyde KD. 2010 Colletotrichum gloeosporioides is not a common pathogen on tropical fruits. Fungal Diversity 44, 33-43.

Phoulivong S. 2011 - Colletotrichum, naming, control, resistance, biocontrol of weeds and current challenges. Current Research in Environmental \& Applied Mycology 1, 53-73.

Politis DJ. 1975 - The identity and perfect state of Colletotrichum graminicola. Mycologia 67, 5662.

Prihastuti H, Cai L, Chan H, McKenzie EHC, Hyde KD. 2009 - Characterization of Colletotrichum species associated with coffee berries in northern Thailand. Fungal Diversity 39, 89-109.

Prusky D. 1996 - Pathogen quiescence in postharvest diseases. Annual Reviews of Phytopathology 34, 413-434.

Rojas EI, Rehner SA, Samuels GJ. 2010 - Colletotrichum gloeosporioides s. l. associated with Theobroma cacao and other plants in Panama: multilocus phylogenies distinguish hostassociated pathogens from asymptomatic endophytes. Mycologia 102, 1318-1338.

Rossman AY, Palm-Hernández ME. 2008 - Systematics of plant pathogenic fungi: Why it matters. Plant Disease 92, 1376-1386.

Sarethy IP, Pan S, Danquah MK. 2014 - Modern taxonomy for microbial diversity. Biodiversity: The Dynamic Balance of the Planet p. 51-68. 
Schoch CL, Seifert KA, Huhndorf S, Robert V, Spouge JL, André Levesque C, Chen W, Fungal Barcoding Consortium. 2012 - Nuclear ribosomal internal transcribed spacer (ITS) region as a universal DNA barcode marker for Fungi. Proceedings of the National Academy of Sciences (USA) 109, 6241-6246.

Sharma G, Gryzenhout M, Hyde KD, Pinnaka AK, Shenoy BD. 2015b - First report of Colletotrichum asianum causing mango anthracnose in South Africa. Plant Disease 99, 725.

Sharma G, Kumar N, Weir BS, Hyde KD, Shenoy BD. 2013a - Apmat gene marker can resolve Colletotrichum species: a case study with Mangifera indica. Fungal Diversity 61, 117-138.

Sharma G, Pinnaka AK, Shenoy BD. 2013b - ITS-based diversity of Colletotrichum from India. Current Research in Environment and Applied Mycology 3, 194-220.

Sharma G, Pinnaka AK, Shenoy BD. 2015a - Resolving the Colletotrichum siamense species complex using ApMat marker. Fungal Diversity 71, 247-264.

Sharma G, Shenoy BD. - 2014 Colletotrichum fructicola and C. siamense are involved in chilli anthracnose in India. Archives of Phytopathology and Plant protection 47, 1179-1194.

Shear CL, Wood AK. 1913 - Studies of fungal parasites belonging to the genus Glomerella. USDA Bureau of Plant Industry 252, 1-110.

Shenoy BD, Jeewon R, Hyde KD. 2007a - Impact of DNA sequence-data on the taxonomy of anamorphic fungi. Fungal Diversity 26, 1-54.

Shenoy BD, Jeewon R, Lam WH, Bhat DJ, Than PP, Taylor PWJ, Hyde KD. 2007b - Morphomolecular characterization and epitypification of Colletotrichum capsici (Glomerellaceae, Sordariomycetes), the causative agent of anthracnose in chilli. Fungal Diversity 27, 197211.

Shivaprakash MR, Appannanavar SB, Dhaliwal M, Gupta A, Gupta S, Gupta A, Chakrabarti A. 2011 - Colletotrichum truncatum: an unusual pathogen causing mycotic keratitis and endophthalmitis. Journal of clinical microbiology 49, 2894-2898.

Silva DN, Talhinhas P, Cai L, Manuel L, Gichuru EK, Loureiro A, Várzea V, Paulo OS, Batista D. $2012 b$ - Host-jump drives rapid and recent ecological speciation of the emergent fungal pathogen Colletotrichum kahawae. Molecular Ecology 21, 2655-2670.

Silva DN, Talhinhas P, Várzea V, Cai L, Paulo OS, Batista D. (2012a) Application of the Apn2/MAT locus to improve the systematics of the Colletotrichum gloeosporioides complex: an example from coffee (Coffea spp.) hosts. Mycologia 104, 396-409.

Snowdon AL. 2010 - Post-harvest diseases and disorders of fruits and vegetables. Volume 2: Vegetables. Manson Publishing.

Spaulding P, Schrenk H. 1903 - The index medicus. Science 17, 751-752.

Sreenivasaprasad S, Meehan BM, Mills PR, Brown AE. 1996 - Phylogeny and systematics of 18 Colletotrichum species based on ribosomal DNA spacer sequences. Genome 39, 499-512.

Stevens FL. 1931 - The ascigerous stage of Colletotrichum lagenarium induced by ultra-violet irradiation. Mycologia 23, 134-139.

Su YY, Noireung P, Liu F, Hyde KD, Moslem MA, Bahkali AH, Abd-Elsalam KA, Cai L. 2011 Epitypification of Colletotrichum musae, the causative agent of banana anthracnose. Mycoscience 52, 376-382.

Sutton BC. 1980 - The Coelomycetes. Commonwealth Mycological Institute, Kew, London.

Sutton BC. 1992 - The genus Glomerella and its anamorph Colletotrichum. In: Colletotrichum Biology, Pathology and Control. J. A. Bailey and M. J. Jeger, eds. CAB International, Wallingford, England. pp. 1-26.

Swamy JS. 2012 - Anthracnose - a devastating pre and post-harvest disease in mango. International Journal of Plant Protection 5, 429-437.

Sydow H. 1913 - Beitrage zur kenntnis der PilzHora des Siidlichen Ostindiens-I. Annales Mycologici 11, 329-330.

Taylor JW, Jacobson DJ, Kroken S, Kasuga T, Geiser DM, Hibbett DS, Fisher MC. 2000 Phylogenetic species recognition and species concepts in fungi. Fungal genetics and biology $31,21-32$. 
Than PP, Jeewon R, Hyde KD, Pongsupasamit S, Mongkolporn O, Taylor PWJ. 2008 Characterization and pathogenicity of Colletotrichum species associated with anthracnose on chilli (Capsicum spp.) in Thailand. Plant Pathology 57, 562-572.

Tode HJ. 1790 - Fungi Mecklenbergensis Selecti 1, 1-64.

Udayanga D, Manamgoda DS, Liu X, Chukeatirote E, Hyde KD. 2013 - What are the common anthracnose pathogens of tropical fruits?. Fungal Diversity 61, 165-179.

Vieira WA, Michereff SJ, de Morais Jr MA, Hyde KD, Câmara MP. 2014 - Endophytic species of Colletotrichum associated with mango in northeastern Brazil. Fungal Diversity 67, 181202.

Wang YC, Hao XY, Wang L, Xiao B, Wang XC, Yang YJ. 2016 - Diverse Colletotrichum species cause anthracnose of tea plants (Camellia sinensis (L.) O. Kuntze) in China. Scientific Reports 6, 35287.

Weir BS, Johnston PR, 2010 - Characterisation and neotypification of Gloeosporium kaki Hori as Colletotrichum horii nom. nov. Mycotaxon 111, 209-219.

Weir BS, Johnston PR, Damm U. 2012 - The Colletotrichum gloeosporioides species complex. Studies in Mycology 73, 115-180.

Welsh J, McClelland M. 1990 - Fingerprinting genomes using PCR with arbitrary primers. Nucleic Acids Research 18, 7213-7218.

White TJ, Bruns TD, Lee S, Taylor JW. 1990 - Amplification and direct sequencing of fungal ribosomal RNA genes for phylogenetics. In PCR protocols: a guide to methods and applications (MA Innis, DH Gelfand, JJ Sninsky, TJ White eds.) Academic Press, Inc., New York, NY. pp. 315-322.

Wikee S, Cai L, Pairin N, McKenzie EHC, Su YY, Chukeatirote E, Thi HN, Bahkali AH, Moslem MA, Abdelsalam K, Hyde KD. 2011 - Colletotrichum species from Jasmine (Jasminum sambac). Fungal Diversity 46, 171-182.

Williams JGK, Kubelik AR, Livak KJ, Rafalski JA, Tingey SV. 1990 - DNA polymorphisms amplified by arbitrary primers are useful as genetic markers. Nucleic Acids Research 18, 6531-6535.

Yang YL, Liu ZY, Cai L, Hyde KD, Yu ZN, McKenzie EHC. 2009 - Colletotrichum anthracnose of Amaryllidaceae. Fungal Diversity 39, 123-146. 